Ivan Christian'

\title{
Inter-Generational Youth Ministry
}

\section{WHY A BALARCED VIEU OF CONחECTING THE GENERATIONS IS ESSENTIHL FOR THE CHURCH}

\section{Mel Walker}

$\mathrm{B}$

uku ini dibuka dengan kalimat introduksi: "our kids are leaving the church!" Kalimat tersebut cukup memberikan gambaran yang bahwa buku ini hadir untuk membahas perihal fenomena eksodus kaum muda dari gereja. Sebagai seorang akademisi kaum muda lulusan dari Clark Summit University dan sebagai seorang veteran pelayan kaum muda yang masih aktif melayani kaum muda di Heritage Baptist Church. Lewat buku ini Mel berusaha memberikan sebuah anjuran kepada gereja-gereja untuk dapat menanggulangi dan melakukan upaya preventif agar fenomena perginya kaum muda dari gereja tidak terulang lagi.

Dalam buku ini, tesis utama Mel adalah gereja perlu melakukan strategi pelayanan kaum muda yang inter-generational, sebuah pelayanan kaum muda yang berusaha untuk mengoneksikan generasi yang satu dengan generasi yang lain dalam proses bertumbuh semakin dewasa dalam iman. Titik pijak Mel dalam buku ini terlihat dengan jelas, yaitu (1) ia tidak setuju dengan pelayanan kaum muda yang mengisolasi anak muda dari keseluruhan, dan (2) ia juga tidak setuju ketika gereja meniadakan pelayanan khusus kepada kelompok usia tertentu dan menggantinya dengan melayani semua usia secara bersamaan, di tempat dan waktu yang sama. Bagi Mel, gereja perlu seimbang dalam menyatukan keuntungan dari pelayanan khusus kepada kelompok usia tertentu dengan pentingnya pelayanan yang meng-

1. Ivan Christian, S.Th., M.I.Kom., alumnus STT Amanat Agung dan Youth Pastor di Gereja Kristen Baptist Jakarø (Jemaat Cengkareng). 
hubungkan generasi yang satu dengan generasi yang lain.

Dalam dua bab pertama, Mel menjelaskan hasil analisisnya tentang beberapa alasan yang menyebabkan terjadinya gap atau segregasi generasi di dalam gereja, mulai dari pengaruh gerakan religius (misalnya, adanya Sekolah Minggu, parachurch khusus melayani kaum muda, dan lain-lain) sampai pada beberapa pengaruh budaya (contohnya, lahirnya sistem pendidikan, kamu muda menjadi target market para pelaku industri, dan sebagainya). Menurut Mel, gereja cenderung memapankan gap generasi dengan kaum muda dengan mengisolasi kegiatan mereka dari orang dewasa atau kelompok umur lainnya. Lebih lanjut, Mel mengingatkan bahwa perlu diingat pelayanan kaum muda eksis karena kehadiran dari laki-laki dan perempuan yang punya hasrat untuk membagikan iman mereka kepada generasi lain.

"Passing the baton", demikianlah gambaran yang Mel gunakan untuk menjelaskan bagaimana seharusnya kebenaran Allah dan iman seseorang dibagikan dari satu generasi ke generasi berikutnya. Bagi Mel, dalam Alkitab terdapat dua institusi utama yang diciptakan oleh Allah, yang terlibat aktif dalam melakukan "passing the baton", yaitu gereja (Ef. 4:11-16; 2Tim. 3:10-17; Mat. 28:18-20) dan keluarga (Ul. 6; Mzm. 78:1-8; Ef. 6:4). Dua institusi itu perlu bekerja sama dengan baik; "parents must raise their children in the 'training and instruction of the Lord' (Eph. 6:4), but God wants His church to be a part of that process."

Pada bab tiga, Mel menjelaskan bahwa
Alkitab memberikan contoh kolaborasi yang baik dari orang tua yang takut akan Allah dan gereja dalam mendidik Yohanes Markus serta Timotius untuk menjadi pengikut Kristus yang setia. Lewat contoh tersebut, jelaslah bahwa jika anak muda memiliki relasi yang baik dengan orang tua dan orang dewasa lainnya yang adalah pengikut Kristus yang setia, maka anak muda akan mendapatkan pengaruh positif yang kuat dalam kehidupan spiritual mereka.

Pada bagian selanjutnya, Mel menjabarkan lebih terperinci tentang apa yang ia maksudkan dari pelayanan kaum muda yang inter-generational. Dalam bagian ini, ia juga membangun argumentasi yang menjelaskan bahwa gereja yang pelayanan one-generational, di mana kelompokkelompok umur bertemu secara terpisah, dan pelayanan multi-generational, di mana setiap kelompok umur bertemu satu sama lain dengan minim interaksi, adalah strategi pelayanan yang tidak efektif dan tidak sesuai dengan apa yang Alkitab ajarkan. Bagi Mel, pelayanan yang inter-generational adalah pelayanan yang bukan hanya sesuai dengan apa yang Alkitab ajarkan, tetapi juga menjawab kebutuhan yang telah terlihat dari hasil penelitian dari Chap Clarkyang mengatakan bahwa "in order for a high school graduate to stay plugged into the church following graduation from high school, he or she needs strong relationships with five significant adults other than their parents." Singkatnya, anak muda membutuhkan kehadiran dan keintiman relasi dengan orang yang dewasa umur dan iman untuk dapat memuridkannya.

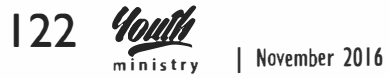


Dalam paradigma pelayanan intergenerational, Mel tidak menganjurkan untuk meniadakan pelayanan berdasarkan kelompok usia. Kunci pelayanan intergenerational terletak pada "the balance of peer, age-group ministries alongside of a genuine and lasting inter-generational ministry." Untuk membangun keseimbangan yang demikian, pada bab enam sampai sepuluh, Mel mencoba menjelaskan bagaimana pelayanan kepada kelompok umur tertentu (anak, kaum muda, dewasa muda, dewasa, dan lanjut usia) dapat dilakukan dalam konteks pelayanan kaum muda yang inter-generational.

Hal yang penting untuk menciptakan pelayanan yang inter-generational di gereja antar kelompok umur adalah hadirnya mentoring yang intensional dari generasi yang lebih dewasa secara umur dan iman kepada generasi berikutnya. Misalnya, para dewasa muda membangun relasi kepada anak muda dan melakukan mentoring. Mel menekankan pada bab 11 bahwa dalam hubungan yang semakin bertumbuh dalam konteks mentoring, ada dua hal yang harus ada, yaitu: (1) firman Allah dan (2) menceritakan hidup yang memiliki kepedulian terhadap anak muda. Dengan kehadiran dua hal tersebut, maka orang yang lebih dewasa dapat menolong anak muda untuk bertumbuh dalam Kristus, menjadi semakin serupa dengan Kristus. Tentu ketika terjadi mentoring antara satu generasi kepada generasi berikutnya, orang tua pun harus melakukan hal yang serupa, yaitu memuridkan anak mereka di dalam Tuhan. Bagi Mel, kolaborasi antara gereja dan keluarga untuk pertumbuhan spiritual dari anak muda akan

\section{Buku ini menawarkan sebuah strategi yang baik dalam pelayanan kaum muda; sebuah strategi yang terkonfirmasi dengan landasan Alkitabiah dan terbukti efektivitasnya secara empiris.}

memberikan "a powerful and lifechanging influence."

Pada bagian akhir buku ini, Mel memberikan beberapa saran kepada pembaca yang ingin menerapkan pelayanan intergenerational dalam gereja. Bagi Mel, adalah sulit untuk mengubah sebuah paradigma pelayanan sebuah gereja, khususnya dari gereja yang age-segregated menuju gereja yang inter-generational. Namun dalam kesulitan itu, Mel menjelaskan bahwa hal mendasar yang perlu diketahui dan dipercayai terlebih dahulu adalah "absolute belief in the reasons for making this shift." Selain itu, Mel juga menasehati pembaca untuk berhati-hati dalam upaya menerapkan pelayanan inter-generational, yaitu "don't throw the baby out with the bathwater", yang berarti jangan mengeliminasi sesuatu yang baik untuk mencoba menghindari sesuatu yang buruk.

Buku ini menawarkan sebuah strategi yang baik dalam pelayanan kaum muda; sebuah strategi yang terkonfirmasi dengan landasan Alkitabiah dan terbukti efektivitasnya secara empiris. Oleh karena itu, buku ini layak untuk dibaca, khususnya bagi para pelayan kaum muda, dan 
bahkan pemimpin gereja secara umum. Selain itu, buku ini menarik untuk dibaca karena Mel juga menawarkan beberapa langkah praktis bagi pembaca untuk menciptakan gereja yang inter-generational. Dengan demikian pembaca tidak diberikan penjelasan yang abstrak saja, namun juga diberikan langkah-langkah konkret untuk menerapkannya.

Namun demikian terdapat beberapa catatan penting untuk buku ini. Pertama, menurut pendapat penulis Mel melakukan beberapa repetisi pembahasan yang tidak perlu, misalnya: (1) penjelasan tentang peran keluarga dan gereja dalam mendidik anak muda di dalam Tuhan dilakukan berulang kali pada bab 3, 4, dan 13; (2) pada bab 8 dan 12, Mel memberikan penjelasan dengan topik yang sama yaitu dewasa muda di usia 19-22 tahun; dan (3) pemberian rekomendasi yang sama dari satu bab kepada bab lainnya, misalnya rekomendasi untuk melibatkan orangyang dewasa secara umur dan iman terdapat di dalam bab 5-8 dan 14-15. Kedua, ada satu topik penting dalam tulisan Mel yang mendapatkan porsi penjelasan yang minim, yaitu topik tentang premis dari pertumbuhan seseorang yang berbeda dari satu kelompok umur dengan ke- lompok umur lain. Premis ini adalah premis yang mendasar untuk menjelaskan topik sepanjang bab 6-10. Namun sangat disayangkan Mel tidak memberikan porsi yang cukup untuk menjelaskan premis tersebut dengan argumentasi yang kuat dan mendalam. Ketiga, menurut penulis dalam bagian "caution", Mel perlu memberikan penjelasan tentang isu tentang ketegangan antar generasi yang didasari dengan adanya ageism, yaitu prasangka berbasis usia dari kelompok umur tertentu kepada kelompok umur lainnya. ${ }^{2}$ Anak muda bisa memiliki prasangka buruk terhadap orang dewasa dan/atau orang yang lanjut usia, dan sebaliknya, orang dewasa dan/atau orang yang lanjut usia memiliki prasangka buruk terhadap kaum muda. ${ }^{3}$ Ketegangan antar kelompok usia tersebut tentu akan berimplikasi pada minimnya relasi interpersonal yang akan terjadi antar pribadi yang berasal dari kelompok usia yang berbeda. Jelaslah ketegangan antar generasi perlu diperhatikan, sehingga gereja dapat meruntuhkan prasangka buruk satu sama lain dan menginisiasi upaya membangun relasi interpersonal yang mengarah kepada pelayanan yang inter-generational.

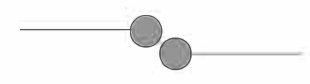

2. Robert N. Butler, "Age-ism: Another Form of Bigotry," The Gerontologist 9 No. 4 (December 1969): 243

3. Michael S. North dan Susan T. Fiske, "An Inconvenienced Youth? Ageism and Its Potential Intergenerational Roots," Psychological Bulletin 138 No. 5 (2012): 982-997.

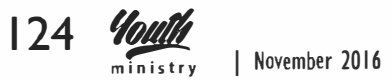

